\title{
Angiogenic growth factors and/or cellular therapy for myocardial regeneration: A comparative study
}

\author{
Juan C. Chachques, MD, PhD \\ Fabricio Duarte, MD \\ Barbara Cattadori, MD \\ Abdel Shafy, MD \\ Nermine Lila, DVM, PhD \\ Gilles Chatellier, MD \\ Jean-Noel Fabiani, MD \\ Alain F. Carpentier, MD, PhD
} From the Department of Cardiovascular
Surgery, European Hospital Georges Pompidou, Paris, France.

Read at the Eighty-third Annual Meeting of The American Association for Thoracic Surgery, Boston, Mass, May 4-7, 2003.

Received for publication Nov 24, 2003; revisions requested $\mathrm{Feb} 2$ 2, 2004; revisions received Feb 24, 2004; accepted for publication April 1, 2004.

Address for reprints: Juan C. Chachques, $\mathrm{MD}, \mathrm{PhD}$, Department of Cardiac Surgery, Pompidou Hospital, 20 rue Leblanc, 75015 Paris, France (E-mail: j.chachques@brs.aphop-paris.fr).

J Thorac Cardiovasc Surg 2004;128:245-53

$0022-5223 / \$ 30.00$

Copyright () 2003 by The American Association for Thoracic Surgery

doi:10.1016/j.jtcvs.2004.04.007
Background: Locally delivered angiogenic growth factors and cell implantation have been proposed for patients with myocardial infarcts without a possibility of percutaneous or surgical revascularization. The goal of this study was to compare the effects of these techniques in an experimental model of myocardial infarct.

Methods: Left ventricular myocardial infarction was created in 27 sheep by ligation of 2 coronary arteries. Three weeks after creation of the infarct, animals were randomized into 4 groups. In group 1, sheep received a culture medium injection to the infarct area (control group); group 2 underwent autologous myoblast implantation; group 3 received vascular endothelial growth factor; and group 4 received injection of both vascular endothelial growth factor and myoblasts. Evaluation included serum troponin IC levels, echocardiography (2-dimensional and color kinesis), and immunohistologic studies for quantitative analysis of capillaries (3 months after surgery).

Results: Four animals died of refractory ventricular fibrillation during myocardial infarction; 2 died after surgery because of stroke and 2 because of infections. Serum troponin increased to $45.6 \pm 4.7 \mathrm{ng} / \mathrm{mL}$ at postinfarction day 2. Echocardiography at 3 months showed a significant limitation of left ventricular dilation in the cell group $(57 \pm 11.1 \mathrm{~mL})$ and in the cell plus vascular endothelial growth factor group (58.6 $\pm 6.6 \mathrm{~mL}$ : control group, $74.4 \pm 11.2 \mathrm{~mL}$; vascular endothelial growth factor group, $68.1 \pm 3.4 \mathrm{~mL}$ ). Color kinesis echography showed important improvements of regional fractional area change in the cell group (from $13.6 \% \pm 0.8 \%$ to $21.1 \%$ $\pm 1.5 \%$ ) and in the cell plus vascular endothelial growth factor group (from $12.8 \%$ $\pm 0.9 \%$ to $18.7 \% \pm 2.3 \%$ ). The number of capillaries increased in the peri-infarct region of the vascular endothelial growth factor group (1036 \pm 75 : control group, $785 \pm 31$; cell group, $830 \pm 75$; cell plus vascular endothelial growth factor group, $831 \pm 83)$.

Conclusions: In the cell therapy groups, regional ventricular contractility improved and heart dilatation was limited compared with either vascular endothelial growth factor or control; thus, postischemic remodeling was reduced. Angiogenesis was demonstrated in the vascular endothelial growth factor group, without improvement of ventricular function and remodeling. To improve local conditions for cell survival, further studies are warranted on prevascularization of myocardial scars with angiogenic therapy. 


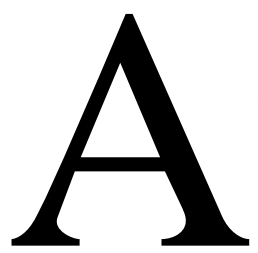

variety of novel angiogenic therapies in the form of proteins, cells, and genes are being evaluated as adjuncts to bypass grafting or as sole therapy for patients who are not candidates for coronary artery surgery. The goal of these interventions is to induce angiogenesis and increase perfusion to ischemic regions of the heart that cannot be adequately revascularized. ${ }^{1-9}$

Another approach for myocardial regeneration consists of the implantation of myogenic cultured cells into infarcted myocardium. Cell engraftment has been detected in histologic studies, ${ }^{10-12}$ but high cell mortality and cells embedded within fibrosis without neovascularization have been observed. This represents a risk for micro re-entry circuits that can generate ectopic ventricular arrhythmias. ${ }^{13-17}$

The encouraging preliminary functional results of cellular cardiomyoplasty have probably been facilitated by the coronary artery bypass grafting or angioplasty procedures performed simultaneously with cell transplantation. ${ }^{18-21}$ Cell survival after implantation in infarcted myocardium is still a challenge, because the oxygen and nutrient supply are limited within the scar.

The goal of this study was to investigate the effects of angiogenic growth factors associated or not with cellular myogenic therapy in myocardial infarcts. We evaluated myocardial function, ventricular remodeling, and angiogenesis.

\section{Materials and Methods \\ Experimental Animals}

In 27 female Rambouillet sheep weighing 21 to $34 \mathrm{~kg}$ (mean, 30 $\pm 3.5 \mathrm{~kg}$ ), a left ventricular (LV) myocardial infarct was surgically created. Three weeks after coronary artery ligation, 4 different treatments were conducted. In group 1 (control group), sheep received in the infarcted area the injection of cell culture medium (Ham's F12) with fetal calf serum. In group 2, autologous cultured myoblasts were implanted. In group 3, $100 \mu \mathrm{g}$ of vascular endothelial growth factor (VEGF; isoform 165) was injected. In group 4 , the myoblasts were associated with VEGF and injected simultaneously into the scar. All procedures were approved by the French National Institute of Health and Medical Research.

\footnotetext{
Anesthetic and Postoperative Management

Premedication of acepromazine $150 \mathrm{mg}$ (Vetranquil) was injected intramuscularly. Thirty minutes later, propofol (Diprivan) was injected intravenously into the left jugular vein at a concentration of $6 \mathrm{mg} / \mathrm{kg}$. The intubation was performed with an endotracheal probe (No. 7). Ventilation was ensured with a Siemens 900C respirator (Siemens AG, Munich, Germany) by use of the following parameters: a volume of $10 \mathrm{~mL} / \mathrm{kg}$, a frequency of 24 breaths/ min, and an inspired oxygen fraction of $60 \%$. Anesthesia was maintained by inhalation of isoflurane $1 \%$ to $2 \%$. Postoperative management of the sheep consisted of cefazolin injected intramuscularly at $1 \mathrm{~g}$ per day over 5 days.
}

\section{Skeletal Muscle Explantation and Myocardial Injury}

A $1-\mathrm{cm}^{3}$ skeletal muscle fragment was explanted from the left posterior femoral biceps of each sheep under sterile conditions. The biopsy tissue was kept in Hanks balanced salt solution (Life Technologies, Rockville, Md) at $4^{\circ} \mathrm{C}$ until the cell culture was started.

Via a left thoracotomy, the ligation of the distal homonymous (equivalent to human left anterior descending) and second diagonal coronary arteries produced a constant transmural infarct. ${ }^{22,23}$ To reduce the risk of ventricular fibrillation, lidocaine $1 \%(2 \mathrm{mg}$. $\mathrm{kg}^{-1} \cdot \mathrm{h}^{-1}$ ) was administered IV during the entire surgical procedure. Thereafter, a drain was placed in the pleural cavity, and the thoracic wall was closed. The drain was removed as soon as the sheep started spontaneous respiration.

The severity of the myocardial injury was expressed in cardiac troponin IC serum levels and was measured 48 hours after infarction. The quantitative determination was assessed with a cardiac troponin IC fluorometric enzyme immunoassay (Stratus; Dade Behring, Deerfield, Ill).

\section{Satellite Cell Isolation and Culture}

Skeletal myoblasts obtained from autologous muscle biopsy samples were isolated, purified, and cultured as previously described. ${ }^{12}$ In brief, the cells were cultured for 3 weeks in Ham's F12 medium containing $20 \%$ fetal calf serum (FCS) and $1 \%$ penicillin/streptomycin. To reduce the number of fibroblasts and achieve a pure myoblast culture, a preplating step was applied on the first passage. The preplating technique was based on the quicker attachment of fibroblasts compared with satellite cells. At 3 weeks, the cultured myoblasts were detached from the cell culture dish with $0.25 \%$ trypsin-ethylenediaminetetraacetic acid. After centrifugation at $300 \mathrm{~g}$ for 5 minutes, 70 million cells were resuspended in $1 \mathrm{~mL}$ of culture medium and used for each transplantation.

\section{Evaluation of VEGF in Cultured Cells}

From human umbilical cords, vascular endothelial cells were isolated and cultured in M199 culture medium (BioWhittaker, Vervier, Belgium) containing 20\% FCS. After 1 week, 100,000 endothelial cells were obtained and grown in the presence of $50 \mu \mathrm{g}$ of VEGF (isoform 165; Laboratory of Molecular Biology, CNRS, University of Toulouse, Toulouse, France). A week later, the final cell number was calculated and compared with a control group cultured without growth factors. There were 900,000 endothelial cells in the cultures that included VEGF versus 550,000 cells in the control group, thus confirming the efficacy of VEGF protein activity.

\section{Cell Injection}

After a 3-week in vitro expansion period, via a median sternotomy, the cell suspension and VEGF were injected into the center and the border of the scar by using an insulin syringe and a retrobulbar ophthalmic needle ( 25 gauge $\times 40 \mathrm{~mm})$. The same volume $(1 \mathrm{~mL})$ of culture medium was injected in group 1 . A suspension containing both myoblasts and VEGF was injected in group 4. The injected area was identified with 2 single sutures associated with metal ligating clips. 


\section{Evaluation of Ventricular Function}

Echocardiography with color kinesis software (Sonos 5500; Hewlett-Packard, Palo Alto, Calif) was performed at cell implantation or at control medium and VEGF injections, 3 weeks after infarction, and at death ( 3 months after surgery) with the aid of a $7-\mathrm{MHz}$ transducer in the epicardial position. End-systolic frames were used for analysis to obtain quantitative information because they contain the entire spatial and temporal histories of the systolic endocardial excursion. ${ }^{24-26}$ Color-encoded images obtained from the short-axis and apical 4-chamber views were automatically divided into wedge-shaped segments with the custom-designed software. This segmentation schema was used to minimize the variability caused by individual differences in LV orientation at end-systole and therefore facilitate intersubject comparisons. Regional wall motion was then assessed by computing the pixel counts in each LV segment. The segments were normalized by the corresponding regional end-systolic area to take into account intersegmental geometric differences and quantify the regional fractional area change (RFAC) for each consecutive frame. In comparison with the regional wall motion, the global cardiac function was measured at the same time points in the 2-dimensional mode. The global parameters included the LV end-diastolic and endsystolic diameters, the shortening fraction, the end-diastolic and systolic volumes, and the ejection fraction. The ejection fraction and shortening were calculated by the Teicholz method and were based on the LV end-systolic and end-diastolic diameters.

\section{Histology and Immunohistochemistry}

All sheep were put to death 3 months after cell or VEGF therapy. The site of myocardial injury was identified and dissected. Four to 5 specimens were used, and each of these was cut into 2 pieces. The first one was fixed in $10 \%$ formol, embedded in paraffin, and sectioned to yield $10-\mu$ m-thick slices. The sections were stained with hematoxylin and eosin. The second piece of each specimen was frozen in liquid nitrogen-cooled isopentane. Frozen biopsy tissue was stored at $-80^{\circ} \mathrm{C}$ until it was processed on a cryostat. When cells were observed in the infarct sections, they were tested with fast myosin heavy chain antibody (MY-32; Sigma Aldrich, St. Louis, Mo), which is specific for the skeletal isoform of adult fast myosin heavy chain.

For immunohistochemical studies, 5 - $\mu \mathrm{m}$-thick sections of frozen tissues were fixed for 10 minutes in cold acetone, and endogenous avidin and biotin sites were blocked (Dako, Glostrup, Denmark). Samples were incubated with the myosin heavy chain antibodies (1:300) in $0.1 \%$ FCS for 1 hour, followed by incubation with biotinyl anti-mouse immunoglobulin (1:200) (Vector Laboratories, Burlingame, Calif), and were finally incubated with streptavidin-cyanine 2 (Amersham Biosciences, Buckinghamshire, United Kingdom) 1:800 in phosphate-buffered saline for $30 \mathrm{~min}-$ utes. The slides were then mounted with the Immuno-mount system (Thermo Shandon, Runcorn, United Kingdom) and studied with an inverted fluorescent microscope (Nikon Eclipse TE300; Nikon Inc, Melville, NY).

Vascular endothelial cells were identified by using antibodies against von Willebrand factor VIII-related antigen (Dako). Subsequent morphometric analyses with optic microscopy permitted the evaluation of capillary density by the count of vessels stained by the antibody on an average of 100 fields for each animal (20 fields for each specimen).

\section{Statistical Methods}

Results are reported as percentage or mean \pm SD. A paired or unpaired Student $t$ test was used to compare the groups when needed. A 1-way analysis of variance was used when more than 2 groups were present. When indicated, a Student-Newman-Keuls multiple comparison test was used as a post hoc test.

\section{Results}

\section{Myocardial Infarction Creation}

Even though antiarrhythmic drugs were administered during the operation, ventricular fibrillation was the major complication: it was present in 9 cases and lethal in 4 animals. Two sheep died after surgery because of stroke and 2 because of infections. At 3 months, the number of surviving animals in each group was as follows: group $1, \mathrm{n}=5$; group $2, \mathrm{n}=6$; group $3, \mathrm{n}=4$; group $4, \mathrm{n}=4$.

The average serum level of cardiac troponin 2 days after infarction was $45 \pm 4 \mathrm{ng} / \mathrm{mL}$. Macroscopically at 3 weeks, a local area of necrosis was consistently observed in the apex and anterolateral LV wall of all animals. After 3 months, the area of necrosis had developed in transmural scars measuring $695 \pm 70 \mathrm{~mm}^{2}$ in the control group, $654 \pm$ $51 \mathrm{~mm}^{2}$ in the cell group, $641 \pm 20 \mathrm{~mm}^{2}$ in the VEGF group, and $681 \pm 35 \mathrm{~mm}^{2}$ in the cell plus VEGF group. The mean ventricular wall thickness in the central part of the lesion was $2.60 \pm 0.17 \mathrm{~mm}$, without important differences between the control and treated groups.

\section{Echocardiography}

The results of the 2-dimensional echocardiographic assessment for global cardiac function are summarized in Tables 1 and 2. The measurements were performed 3 and 12 weeks after myocardial injury. With a paired Student $t$ test, the 2 time points were compared within the cell-treated groups. A statistical difference was not found for LV ejection fraction, but the difference was significant for LV end-diastolic volume; there was significant ventricular dilation in the control and VEGF groups. Otherwise, in the cell-treated groups, LV volume was stable at 3 months, passing from $55.6 \pm 4.6 \mathrm{~mL}$ at 3 weeks after infarction to $57 \pm 11.1 \mathrm{~mL}$ and from 55.7 $\pm 5.3 \mathrm{~mL}$ to $58.6 \pm 6.6 \mathrm{~mL}$ in groups 2 and 4 , respectively. No significant differences were observed between groups 2 and 4.

Echocardiography with color kinesis software showed no important differences at baseline among the 4 groups. At 12 weeks, the percentage of end-systolic area of the regional LV wall motion, expressed as RFAC, showed a significant increase in regional function in cell-transplanted groups, from $13.6 \% \pm 0.8 \%$ before cell transplantation to $21.1 \% \pm$ $1.5 \%$ at 3 months and from $12.8 \% \pm 0.9 \%$ before versus $18.7 \% \pm 2.3 \%$ after cell plus VEGF therapy. The RFAC in 
TABLE 1. Echocardiographic studies after myocardial infarction

\begin{tabular}{|c|c|c|c|c|c|c|c|c|}
\hline \multirow[b]{2}{*}{ Group } & \multicolumn{2}{|c|}{ LVEDV (mL) } & \multicolumn{2}{|c|}{ LVESV (mL) } & \multicolumn{2}{|c|}{ EF (\%) } & \multicolumn{2}{|c|}{ RFAC $(\%)$ color kinesis } \\
\hline & 3 wk & 12 wk & 3 wk & 12 wk & $3 \mathbf{w k}$ & 12 wk & 3 wk & 12 wk \\
\hline Control & $52.4 \pm 2.1$ & $74.4 \pm 11.2$ & $31.3 \pm 2.8$ & $44.6 \pm 5.6$ & $40.2 \pm 5.9$ & $39.8 \pm 3.6$ & $11.6 \pm 0.8$ & $10.5 \pm 1.7$ \\
\hline Cells & $55.6 \pm 4.6$ & $57 \pm 11.1$ & $32.8 \pm 3.1$ & $32.8 \pm 8.8$ & $42.7 \pm 2$ & $43.3 \pm 4.3$ & $13.6 \pm 0.8$ & $21.1 \pm 1.5$ \\
\hline VEGF & $53.8 \pm 1.6$ & $68.1 \pm 3.4$ & $31.3 \pm 1.2$ & $38.3 \pm 4.9$ & $41.8 \pm 3.1$ & $43.3 \pm 4.1$ & $17.5 \pm 1.3$ & $11.9 \pm 0.7$ \\
\hline Cells + VEGF & $55.7 \pm 5.3$ & $58.6 \pm 6.6$ & $34.5 \pm 5.4$ & $34.6 \pm 5.9$ & $38.3 \pm 5.1$ & $40.8 \pm 9.6$ & $12.8 \pm 0.9$ & $18.7 \pm 2.3$ \\
\hline
\end{tabular}

Data are means $\pm 1 \mathrm{SD}$. LVEDV, Left ventricular end-diastolic volume; $L V E S V$, left ventricular end-systolic volume; $E F$, ejection fraction; $R F A C$, regional fractional area change; $V E G F$, vascular endothelial growth factor.

TABLE 2. Echocardiographic results: Analysis of variance

\begin{tabular}{|c|c|c|c|c|c|c|c|}
\hline & DF & $\begin{array}{l}\text { Sum of } \\
\text { squares }\end{array}$ & $\begin{array}{l}\text { Mean } \\
\text { square }\end{array}$ & $F$ value & $P$ value & Lambda & Power \\
\hline \multicolumn{8}{|c|}{ EF (\%) difference } \\
\hline Group & 3 & 20,414 & 6,805 & 0.267 & .8483 & 0.800 & 0.089 \\
\hline Residual & 15 & 382,533 & 25,502 & & & & \\
\hline \multicolumn{8}{|c|}{ LVEDV (mL) difference } \\
\hline Group & 3 & 1439,825 & 479,942 & 6,725 & .0043 & 20,174 & 0.931 \\
\hline Residual & 15 & 1070,579 & 71,372 & & & & \\
\hline \multicolumn{8}{|c|}{ LVESV (mL) difference } \\
\hline Group & 3 & 602,839 & 200,946 & 4,713 & .0164 & 14,138 & 0.802 \\
\hline Residual & 15 & 639,601 & 42,640 & & & & \\
\hline
\end{tabular}

$D F$, Degrees of freedom; $E F$, ejection fraction; $L V E D V$, left ventricular end-diastolic volume; $L V E S V$, left ventricular end-systolic volume.

groups 1 and 3 (without cell transplantation) did not increase: it was $11.6 \% \pm 0.8 \%$ at the moment of medium injection versus $10.5 \% \pm 1.7 \%$ at the 3 -month follow-up, and it was $17.5 \% \pm 1.3 \%$ before VEGF injection versus $11.9 \% \pm 0.7 \%$ at 3 months. No significant differences were observed between groups 2 and 4. The color-encoded images, using backscatter, identified the pixel transition from tissue to blood, which were updated on a frame-by-frame basis, resulting in color overlays.

\section{Identification of Myoblasts}

By histologic analysis with hematoxylin and eosin stain, in all groups we found infarcted areas characterized by the replacement of healthy myocardium by adipose and fibrous tissue, as well as a low inflammatory response. Postinfarction myocardial scars in sheep are predominantly infiltrated by adipose tissue. By immunohistochemical analysis, sections from 7 of 10 sheep treated with cells were positively stained with myosin heavy chain (the skeletal isoform of adult fast myosin heavy chain), and satellite cells were detected. This antibody did not react with healthy or ischemic cardiac sections, nor did it stain the type 1 fibers (slow twitch) of the skeletal muscle sections. Furthermore, in 4 of these animals, elongated skeletal muscle cells structures were observed that resembled multinucleated myotubes and in some sections presented a fibrillar configuration (Figure 1). No skeletal muscle cells were found in the healthy myocardium.

\section{Angiogenesis}

Some degree of angiogenesis developed at the periphery of the infarct region and not in the center of the scar. An important increase in the number of capillaries $(P=.0443)$ was observed in the group treated with protein-based growth factors. The mean number of capillaries in the peri-infarct area of the VEGF group was $1036 \pm 75$ (control group, $785 \pm 31$; cell group, $830 \pm 75$; cell plus VEGF group, $831 \pm 83$ ). Significant angiogenesis was not detected in the center of the scar, and the number of capillaries was $144 \pm 64$ in the control group, $278 \pm 82$ in the cell group, $218 \pm 79$ in the VEGF group, and $254 \pm 87$ in the cell plus VEGF group (Figure 2).

\section{Discussion}

Coronary artery bypass grafting is the most common cardiac operation in Europe and the United States; however, in $20 \%$ of patients, it is not possible to achieve complete revascularization. Cell transplantation, growth factors, and gene therapy represent emerging biologic treatments conceived to improve myocardial viability in ischemic heart failure. A biologic regenerative approach to patients at risk of congestive heart failure may be effective for reversing the postischemic remodeling process, which is characterized by progressive expansion of the initial infarct area and dilation of the LV lumen, with cardiomyocyte replacement by fibrous tissue deposition in the ventricular wall. 


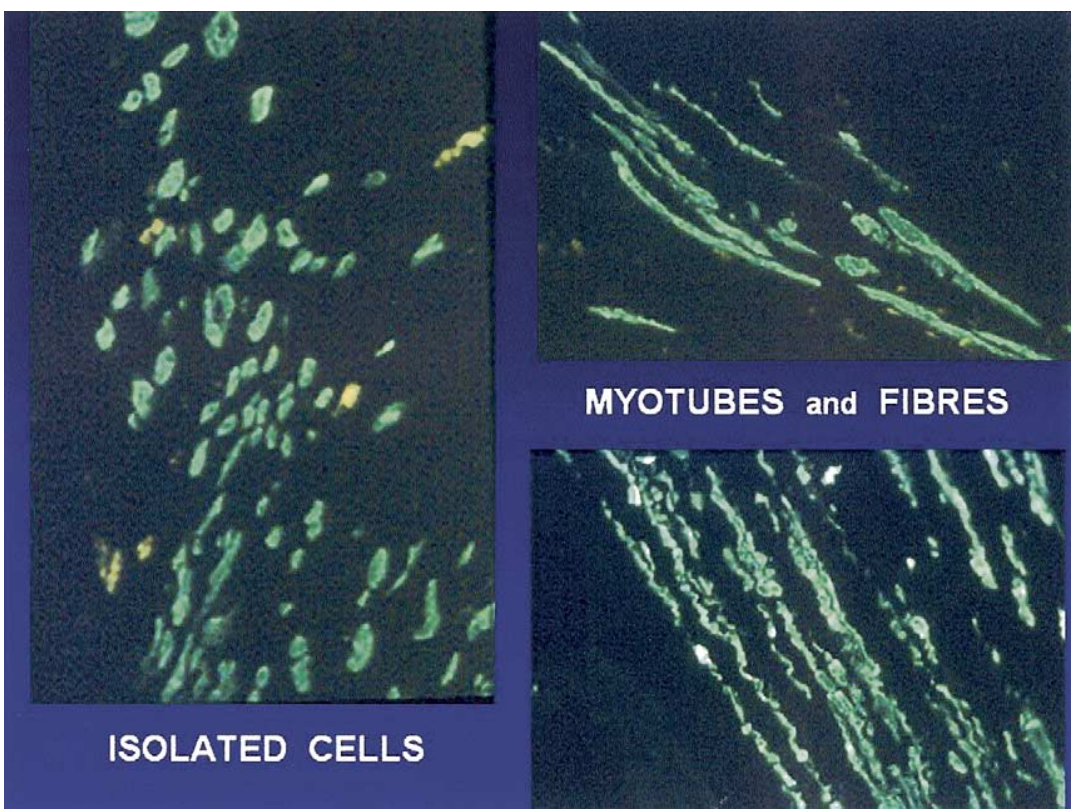

Figure 1. Histoimmunologic studies at 3 months of the infarct region, showing isolated grafted myoblasts organized in multinucleated myotubes and presenting in some sections a fibrillar configuration. Stain with MY-32 antibody to fast-twitch skeletal myosin (original magnification, $200 \times$ ).

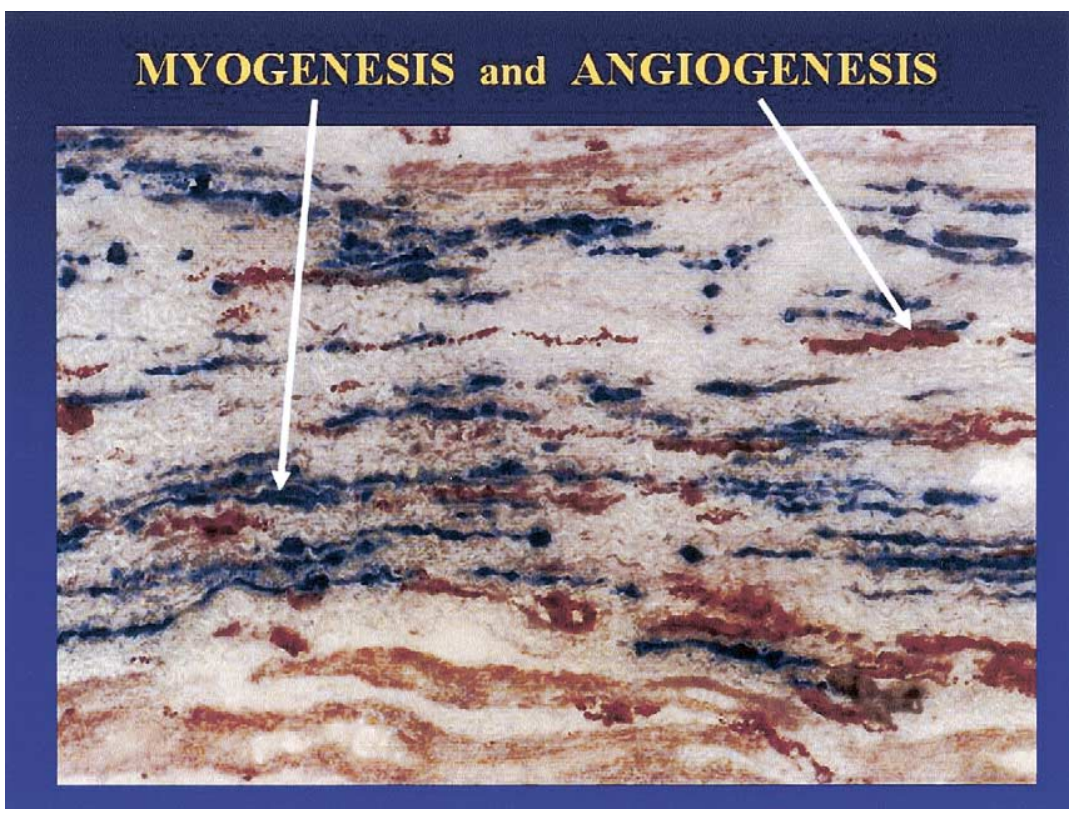

Figure 2. Histologic assessment of sheep myocardial infarction after treatment with cells and VEGF. The infarct scar is penetrated by grafted myoblasts (blue) and neovessels (red); healthy myocardial tissue can be observed in the upper and lower borders of the figure. Myogenesis (blue stain) was identified by using fast myosin heavy chain antibodies. Angiogenesis (red stain) was evaluated by the identification of endothelial cells with anti-von Willebrand factor VIII antibody (double-stain technique; original magnification, 200×).

The goal of this study was to compare the effects of myoblast implantation and the injection of VEGF in a model of myocardial infarct in large animals. Our results showed that myogenic cell transplantation, associated or not with angiogenic growth factors, improved regional myocardial contractility and limited LV chamber remodeling. In 
contrast, no functional benefit was shown in the group treated with VEGF. Similar results have been observed in another experimental study in which intramyocardial and intracoronary delivery of basic fibroblast growth factor in porcine hibernating myocardium resulted in improved perfusion without functional advantages. ${ }^{27}$ It can be postulated that the administration of VEGF 3 weeks after creation of the infarct model could be considered too late to achieve functional benefits or that this therapy may require long time periods to develop. Probably postimplant cell mortality starts too soon, ie, before the development of neovascularization. For this reason, angiogenic growth factors could be delivered into myocardial infarct areas several days before cell transplantation to first improve local perfusion conditions for cell survival (preconditioning).

Angiogenesis was observed only in animals treated with VEGF alone (ie, not when associated with myoblast transplantation). Similar results were observed in human pathologic studies after myoblast implantation, confirming the lack of angiogenesis. ${ }^{13,14}$ Simultaneous delivery of VEGF and cells did not show angiogenic effects. This finding is unexpected and is currently unexplained. It could be hypothesized that the combination of both products at the moment of injection induced some degree of chemical or biologic inactivation of the VEGF properties or that the growth factor effect can be reduced or masked by the inflammatory reaction generated by the injected cells and bovine culture medium (FCS).

The mechanism of the beneficial effects of cellular cardiomyoplasty achieved in preclinical studies and clinical trials needs to be elucidated. It was suggested that cell transplantation stabilizes the infarct region, induces angiogenesis, and modifies the response of the remaining myocardium to the infarct. Angiogenesis seems to be obtained when bone marrow-derived cells are implanted for myocardial regeneration. ${ }^{12}$ The effects of cell transplantation seem to be related to a profound biologic response to cell engraftment that influences both regional and global remodeling of the heart. ${ }^{10-12,28}$ These effects on the ischemic failing heart can be limited by the local environment, because the fibrotic area in and around infarct regions is not adequate for cells to survive in: they are exposed to poor conditions in which certain requirements cannot be adequately supplied because the oxygen and nutrients supply are reduced within the scar.

In our study, histologic demonstration of cell engraftment was achieved in $70 \%$ of cases. The histologic studies were performed at 3 months in selected areas of the LV and not in the whole heart (as is done for small animals). It is possible that the selection of heart tissue samples for microscopic examination did not correspond exactly with the cell injection areas, and there were difficulties related to the fact that the autopsies were performed after 2 cardiac oper- ations (creation of myocardial infarction and VEGF or cell implantation). Furthermore, the nonobservation of cells in 3 sheep could be because we used specific fast type myosin heavy chain antibodies for identification of skeletal myoblasts in the myocardium. However, the implanted cells could have changed from a fast type to a slow myosin type after a 3-month implantation in a beating heart, as observed in previous studies, ${ }^{11}$ or this could occur simply because there were slow myosin heavy chain-type myoblasts in the original skeletal muscle biopsy.

Therapeutic angiogenesis is a strategy designed to amplify the native angiogenic process and enhance the reperfusion of ischemic tissues. There are 3 approaches to induce angiogenesis and vasculogenesis: proteins, cells, and gene therapy. The administration of growth factors in the form of proteins presents risks of systemic effects, inducing problematic angiogenesis in the retina, expanding atherosclerotic lesions, or potentiating growth and metastasis of occult tumors. However, these deleterious effects have not been observed in current clinical trials, in which therapeutic angiogenesis seems to provide improvement in angina and exercise treadmill test results in patients with stable exertional angina. ${ }^{29,30}$ Transplanted endothelial cells removed from the intima of arteries and veins can stimulate angiogenesis and can be incorporated into the new vessels, increasing regional perfusion in myocardial scar tissue. ${ }^{4}$ Bone marrow from adult humans contains endothelial precursors with phenotypic and functional characteristics of embryonic hemangioblasts that can be used to directly induce new blood vessel formation in the infarct bed (vasculogenesis) and to induce proliferation of preexisting vasculature (angiogenesis) after myocardial infarction or in chronic limb ischemia. ${ }^{31-34}$ Gene therapy consists of the introduction of new genetic material into somatic cells to synthesize proteins that are missing, defective, or desired for specific therapeutic purposes. ${ }^{35-37}$ Growth factor gene therapy presents risks related to stability, unregulated expression, and adverse responses to transfection vectors. ${ }^{9,38}$

To enhance the effects of cellular cardiomyoplasty, hepatocyte growth factor has been recently proposed by Miyagawa and associates ${ }^{39}$ as a combined therapy. The authors hypothesized that transfection of the gene for human hepatocyte growth factor combined with cellular cardiomyoplasty might regenerate the impaired myocardium. Preliminary results are encouraging, and the main effect seems to be the reduction of fibrosis in the infarct scar. In another article, Sakakibara and associates ${ }^{40}$ showed prevascularization of myocardial infarcts with gelatin microspheres containing basic fibroblast growth factor to enhance the effects of cardiomyocyte transplantation. According to the studies of von Lewinski and colleagues ${ }^{41}$ and Lai and colleagues, ${ }^{42}$ insulin-like growth factor 1 seems to be a promising therapeutic alternative because it exerts $\mathrm{Ca}^{2+}$-dependent positive 
inotropic effects in failing human myocardium. Angiogenic and myogenic growth factors (VEGF, basic fibroblast growth factor, and RGTA [ReGeneraTing Agent]) have been evaluated by our group in a cardiomyoplasty model, and they resulted in improved vascularization and trophicity of skeletal muscles. ${ }^{43}$

As suggested by our experimental results and the international literature, skeletal myoblasts and bone marrow cells that engraft in the infarct region alter the elastic properties of the transplantation site, limit infarct expansion, and prevent the ventricular dilation and remodeling that results in congestive heart failure. ${ }^{44,45}$ Our histologic studies and clinical pathologic data ${ }^{13,14}$ could not demonstrate any angiogenic effects of myoblast grafting. To improve the hypoxic myocardial environment, prevascularization of myocardial infarcts could be considered before cellular cardiomyoplasty. This combined therapeutic approach could be facilitated by catheter-based interventional cardiology procedures. ${ }^{46}$ It can be postulated that staged angiogenic and myogenic therapeutic procedures may be beneficial for myocardial regeneration. Further studies are warranted to confirm the efficacy of such a 2-stage strategy.

Many questions concerning the mechanisms of myocardial regeneration will probably be answered by upcoming investigations. It is to be hoped that the fields of cell therapy, tissue engineering, growth factors, and gene therapy might mutually benefit from their respective advances. These fields must be considered as complementary, with combined strategies. The ultimate goal is the improvement of the outcome of patients with severe ischemic and nonischemic myocardial diseases. ${ }^{47}$

This study was performed in an infarct model that resulted in 30\% sheep mortality. Therefore, the numbers of animals in the groups were reduced at the moment of evaluation. The absence of differences observed between groups either can be due to insufficient power of our analysis because of the small number of animals or can be due to a real absence of treatment effects at the 3-month followup. These therapies may require longer periods to develop. The number of cells engrafted in the myocardium should represent important information for evaluating the combination of growth factors with cellular therapy. Simultaneous or successive applications of these approaches deserve additional consideration. These aspects were not assessed in our study and require further investigation.

\section{References}

1. Simons M, Bonow RO, Chronos NA, Cohen DJ, Giordano FJ, Hammond HK, et al. Clinical trials in coronary angiogenesis: issues, problems, consensus-an expert panel summary. Circulation. 2000; 102:E73-86.

2. Laham RJ, Rezaee M, Post M, Xu X, Sellke FW. Intrapericardial administration of basic fibroblast growth factor: myocardial and tissue distribution and comparison with intracoronary and intravenous administration. Catheter Cardiovasc Interv. 2003;58:375-81.
3. Henry TD, Rocha-Singh K, Isner JM, Kereiakes DJ, Giordano FJ, Simons M, et al. Intracoronary administration of recombinant human vascular endothelial growth factor to patients with coronary artery disease. Am Heart J. 2001;142:872-80.

4. Kim EJ, Li RK, Weisel RD, Mickle DAG, Jia ZQ, Tomita S, et al. Angiogenesis by endothelial cell transplantation. J Thorac Cardiovasc Surg. 2001;122:963-71.

5. Hamano K, Li TS, Kobayashi T, Hirata K, Yano M, Kohno M, et al. Therapeutic angiogenesis induced by local autologous bone marrow cell implantation. Ann Thorac Surg. 2002;73:1210-5.

6. Al-Khaldi A, Al-Sabti H, Galipeau J, Lachapelle K. Therapeutic angiogenesis using autologous bone marrow stromal cells: improved blood flow in a chronic limb ischemia model. Ann Thorac Surg. 2003;75:204-9.

7. Funatsu T, Sawa Y, Ohtake S, Takahashi T, Matsumiya G, Matsuura $\mathrm{N}$, et al. Therapeutic angiogenesis in the ischemic canine heart induced by myocardial injection of naked complementary DNA plasmid encoding hepatocyte growth factor. J Thorac Cardiovasc Surg. 2002; 124:1099-105.

8. Khan TA, Sellke FW, Laham RJ. Gene therapy progress and prospects: therapeutic angiogenesis for limb and myocardial ischemia. Gene Ther. 2003;10:285-91.

9. Lee RJ, Springer ML, Blanco-Bose WE, Shaw R, Ursell PC, Blau HM. VEGF gene delivery to myocardium: deleterious effects of unregulated expression. Circulation. 2000;102:898-901.

10. Rajnoch C, Chachques JC, Berrebi A, Bruneval P, Benoit MO, Carpentier A. Cellular therapy reverses myocardial dysfunction. $J$ Thorac Cardiovasc Surg. 2001;121:871-8.

11. Ghostine S, Carrion C, Souza LC, Richard P, Bruneval P, Vilquin JT, et al. Long-term efficacy of myoblast transplantation on regional structure and function after myocardial infarction. Circulation. 2002; 106(Suppl 1):I-131-6.

12. Chiu RCJ. Therapeutic cardiac angiogenesis and myogenesis: the promises and challenges on a new frontier. J Thorac Cardiovasc Surg. 2001;122:851-2.

13. Pagani FD, DerSimonian H, Zawadzka A, Wetzel K, Edge AS, Jacoby $\mathrm{DB}$, et al. Autologous skeletal myoblasts transplanted to ischemiadamaged myocardium in humans. Histologic analysis of cell survival and differentiation. $J$ Am Coll Cardiol. 2003;41:879-88.

14. Hagege AA, Carrion C, Menasche P, Vilquin JT, Duboc D, Marolleau JP, et al. Viability and differentiation of autologous skeletal myoblast grafts in ischaemic cardiomyopathy. Lancet. 2003;361:491-2.

15. Leobon B, Garcin I, Menasche P, Vilquin JT, Audinat E, Charpak S. Myoblasts transplanted into rat infarcted myocardium are functionally isolated from their host. Proc Natl Acad Sci U S A. 2003;100:7808-11.

16. Soliman AM, Taylor DA, Thompson RB, Morimoto Y, McMichael M, Crater S, et al. Assessment of electrical instability after autologous myoblast transplantation in a rabbit infarct model. Circulation. 2003; 108(Suppl 4):IV-547.

17. Minami E, Reinecke H, Murry CE. Skeletal muscle meets cardiac muscle: friends or foes? J Am Coll Cardiol. 2003;41:1084-6.

18. Herreros J, Prosper F, Perez A, Gavira JJ, Garcia-Velloso MJ, Barba $\mathrm{J}$, et al. Autologous intramyocardial injection of cultured skeletal muscle-derived stem cells in patients with non-acute myocardial infarction. Eur Heart J. 2003;24:2012-20.

19. Menasche P, Hagege AA, Vilquin JT, Desnos M, Abergel E, Pouzet B, et al. Autologous skeletal myoblast transplantation for severe postinfarction left ventricular dysfunction. J Am Coll Cardiol. 2003;41: 1078-83.

20. Stamm C, Westphal B, Kleine HD, Petzsch M, Kittner C, Klinge H, et al. Autologous bone-marrow stem-cell transplantation for myocardial regeneration. Lancet. 2003;361:45-6.

21. Strauer BE, Brehm M, Zeus T, Kostering M, Hernandez A, Sorg RV, et al. Repair of infarcted myocardium by autologous intracoronary mononuclear bone marrow cell transplantation in humans. Circulation. 2002;106:1913-8

22. Markovitz LJ, Savage EB, Ratcliffe MB, Bavaria JE, Kreiner G, Iozzo $\mathrm{RV}$, et al. Large animal model of left ventricular aneurysm. Ann Thorac Surg. 1989;48:838-45.

23. Llaneras MR, Nance ML, Streicher JT, Lima JA, Savino JS, Bogen 
DK, et al. Large animal model of ischemic mitral regurgitation. Ann Thorac Surg. 1994;57:432-9.

24. Mor-Avi V, Lang RM. Recent advances in echocardiographic evaluation of left ventricular anatomy, perfusion, and function. Cardiol Rev. 2001;9:146-59.

25. Ishii K, Miwa K, Makita T, Okuda N, Aoyama T. Diagnosis of coronary vasospasm by detection of postischemic regional left ventricular delayed relaxation using echocardiographic evaluation with color kinesis. Clin Cardiol. 2003;26:477-82.

26. Mor-Avi V, Korcarz CE, Collins KA, Decara JM, Caiani EG, Lang RM. Simultaneous real-time echocardiographic imaging of myocardial perfusion and regional function using color-encoded, contrast-enhanced power modulation. J Am Soc Echocardiogr. 2003;16:1258-66.

27. Biswas SS, Hughes GC, Scarborough JE, Domkowski PW, Diodato L, Smith ML, et al. Intramyocardial and intracoronary basic fibroblast growth factor in porcine hibernating myocardium: a comparative study. J Thorac Cardiovasc Surg. 2004;127:34-43.

28. Chachques JC, Cattadori B, Herreros J, Prosper F, Trainini JC, Blanchard D, et al. Treatment of heart failure with autologous skeletal myoblasts. Herz. 2002;27:570-8.

29. Henry TD, Annex BH, McKendall GR, Azrin MA, Lopez JJ, Giordano FJ, et al. VIVA Investigators. The VIVA trial: Vascular endothelial growth factor in Ischemia for Vascular Angiogenesis. Circulation. 2003;107:1359-65.

30. Sellke FW, Ruel M. Vascular growth factors and angiogenesis in cardiac surgery. Ann Thorac Surg. 2003;75:S685-90.

31. Tse HF, Kwong YL, Chan JK, Lo G, Ho CL, Lau CP. Angiogenesis in ischaemic myocardium by intramyocardial autologous bone marrow mononuclear cell implantation. Lancet. 2003;361:47-9.

32. Assmus B, Schächinger V, Teupe C, Britten M, Lehmann R, Dobert N, et al. Transplantation of progenitor cells and regeneration enhancement in acute myocardial infarction (TOPCARE-AMI). Circulation. 2002;106:3009-17.

33. Kocher AA, Schuster MD, Szabolcs MJ, Takuma S, Burkhoff D, Wang J, et al. Neovascularization of ischemic myocardium by human bone-marrow-derived angioblasts prevents cardiomyocyte apoptosis, reduces remodeling and improves cardiac function. Nat Med. 2001;7: 430-6.

34. Tateishi-Yuyama E, Matsubara H, Murohara T, Ikeda U, Shintani S, Masaki $\mathrm{H}$, et al. Therapeutic angiogenesis for patients with limb ischaemia by autologous transplantation of bone-marrow cells: a pilot study and a randomised controlled trial. Lancet. 2002;360:427-35.

35. Suzuki K, Murtuza B, Smolenski RT, Sammut IA, Suzuki N, Kaneda Y, et al. Cell transplantation for the treatment of acute myocardial infarction using vascular endothelial growth factor-expressing skeletal myoblasts. Circulation. 2001;104(Suppl 1):I-207-12.

36. Vale PR, Losordo DW, Milliken CE, McDonald MC, Gravelin LM, Curry CM, et al. Randomized, single blind, placebo-controlled pilot study of catheter-based myocardial gene transfer for therapeutic angiogenesis using left ventricular electromechanical mapping in patients with chronic myocardial ischemia. Circulation. 2001;103:213843 .

37. Horvath KA, Doukas J, Lu CY, Belkind N, Greene R, Pierce GF, et al. Myocardial functional recovery after fibroblast growth factor 2 gene therapy as assessed by echocardiography and magnetic resonance imaging. Ann Thorac Surg. 2002;74:481-7.

38. Sellke FW. Gene therapy in cardiac surgery: is there a role? J Thorac Cardiovasc Surg. 2003;125:994-7.

39. Miyagawa S, Sawa Y, Taketani S, Kawaguchi N, Nakamura T, Matsuura $\mathrm{N}$, et al. Myocardial regeneration therapy for heart failure: hepatocyte growth factor enhances the effect of cellular cardiomyoplasty. Circulation. 2002;105:2556-61.

40. Sakakibara Y, Nishimura K, Tambara K, Yamamoto M, Lu F, Tabata $\mathrm{Y}$, et al. Prevascularization with gelatin microspheres containing basic fibroblast growth factor enhances the benefits of cardiomyocyte transplantation. J Thorac Cardiovasc Surg. 2002;124:50-6.

41. von Lewinski D, Voss K, Hulsmann S, Kogler H, Pieske B. Insulinlike growth factor- 1 exerts $\mathrm{Ca}^{2+}$-dependent positive inotropic effects in failing human myocardium. Circ Res. 2003;92:169-76.

42. Lai HC, Liu TJ, Ting CT, Sharma PM, Wang PH. Insulin-like growth factor-1 prevents loss of electrochemical gradient in cardiac muscle mitochondria via activation of PI 3 kinase/Akt pathway. Mol Cell Endocrinol. 2003;205:99-106.

43. Zakine G, Martinod E, Fornes P, Sapoval M, Carpentier A, Chachques JC. Growth factors improve latissimus dorsi muscle vascularization and trophicity after cardiomyoplasty. Ann Thorac Surg. 2003;75:54954.

44. Tambara K, Sakakibara Y, Sakaguchi G, Lu F, Premaratne GU, Lin X, et al. Transplanted skeletal myoblasts can fully replace the infarcted myocardium when they survive in the host in large numbers. Circulation. 2003;108(Suppl 1):II-259-63.

45. Thompson RB, Emani SM, Davis BH, van den Bos EJ, Morimoto Y, Craig D, et al. Comparison of intracardiac cell transplantation: autologous skeletal myoblasts versus bone marrow cells. Circulation. 2003; 108(Suppl 1):II-264-71.

46. Chachques JC, Herreros J, Vega I. Catheter "Cell-Fix" for diagnostic and injection in cardiology treatments. French Patent 03 13719, 2003 (international PCT application; http://www.wipo.org/pct).

47. Chachques JC, Acar C, Herreros J, Trainini J, Prosper F, D'Attellis N, et al. Cellular cardiomyoplasty: clinical application. Ann Thorac Surg. 2004;77:1121-30.

\section{Discussion}

Dr Frank W. Sellke (Boston, Mass). Which isoform of VEGF did you administer, and exactly where did you inject it: into the infarct area or the border area?

Dr Chachques. We administered VEGF isoform 165. We performed $70 \%$ of our injections in the peri-infarct area (in the intermediate area) and $30 \%$ in the middle of the scar. We have demonstrated in previous studies that the cell survival is better in the intermediate area. We injected the cells together with the growth factors that were included in the injection medium. This implantation was made with a 25 -gauge $\times 40-\mathrm{mm}$ retrobulbar ophthalmology needle.

Dr Sellke. Did you really think that the VEGF would improve contractility in the scar and decrease the LV dimension, or was it just to precondition the heart for the injection of the cells?

Dr Chachques. All the groups that have worked with angiogenic growth factors for myocardial infarction, including your group, have tried to demonstrate that angiogenic growth factors could improve both vascularization and myocardial function. In this direction, we tried to investigate whether angiogenic growth factors associated or not with cellular therapy would improve myocardial function. In our study, we demonstrated angiogenesis only in myocardial infarcts treated with VEGF. We think that in the future, the best way for functional improvement will be a 2-step procedure: first, angiogenesis induction, and second, cellular therapy. Angiogenic growth factors could be delivered by endoventricular catheters, and then, in a second step, the cells could be surgically implanted.

Dr Masashi Komeda (Kyoto, Japan). As you said, the 2-step application of angiogenesis factors is very useful. We presented that result at the American Heart Association meeting a couple of years ago when we used the basic fibroblast growth factor slow release, not just direct injection, in advance- 1 week before cell transplantation. The result was a lot better, in terms of both function and angiogenesis. I will bet that if you use either gene therapy or slow release, particularly in advance, the result will be different. We see a lot more angiogenesis, not $20 \%$ more but $50 \%$ more or $80 \%$ more, and even the function is better.

Dr Chachques. We tried to perform our protocol in only one surgical procedure to avoid the risk of reoperations in animals with heart failure. The best approach would be a 2-step procedure. 
Dr Terrence M. Yau (Toronto, Ontario, Canada). I notice that you did not see any evidence of angiogenesis in this preparation, although transplantation of a number of cell types has been described to induce at least modest angiogenesis in a variety of other models. Have you looked at microspheres or any other evaluation of regional blood flow?

Also, I see that you colocalized your growth factors and your cell therapy by putting the growth factors in the suspended medium, but have you tried looking at either depot protein therapy or transfecting your cells with angiogenic growth factors to try to prolong the expression of those growth factors? We have previously reported that transplantation of cells transfected with VEGF can dramatically increase the degree of local angiogenesis in a myocardial scar, and we believe that this combination may be potentially therapeutically useful.

Dr Chachques. The goal of our study was to develop a safe therapeutic approach for heart failure that can be easily reproduced by cardiac surgeons. For this reason, we used growth factors in the form of proteins associated or not with intramyocardial cell implantation. This combined procedure could be improved according to your remarks.

Dr Sidney Levitsky (Boston, Mass). Do you have any evidence from studying the postmortem specimens concerning the viability of the cells that you implanted? Is there any relationship of the volume of cells that survived and the postoperative ejection fraction? Were you able to see any correlation, or is this just an all-or-nothing phenomenon?

Dr Chachques. The immunohistologic study that I showed demonstrated viable cells that were reactive against specific antibodies. We did not quantify the cells identified in histologic slides. It is important to remark that one of the main goals of cell therapy is to transform the fibrotic infarcted scar into living tissue. The transplanted cells can be organized into the myocardium in myotubes and myofibers. This configuration is appropriate for cardiac remodeling. The elasticity of the ventricular wall can be improved, and the size of the scar can be reduced. I think that this is very positive, because in ischemic cardiomyopathies, one of the most important problems is the ventricular remodeling process, which can be stabilized or reversed by this cellular organization.

Dr Georg Lutter (Freiburg, Germany). Very interesting paper, Dr Chachques. First, I would like to know whether you analyzed your area at risk and infarction area. Second, I am wondering why you used VEGF as a growth factor, because it is known to induce angiogenesis, and whether what you need long-term and in a chronic model is arteriogenesis, for instance, induced by fibroblast growth factor. We have already used fibroblast growth factor 1 in humans, and we have seen good angiogenesis and maybe also arteriogenesis. Could you explain why you chose VEGF and not, for instance, granulocyte macrophage colony-stimulating factor or fibroblast growth factor?

Dr Chachques. We tried to demonstrate in this study that new biologic procedures for myocardial diseases can be positively associated. We started using VEGF, but we think that it is a very interesting idea to also use basic fibroblast growth factor or other growth factors, because basic fibroblast growth factor also has the possibility to induce myogenesis and not only angiogenesis. These properties are very important for the future of cellular cardiomyoplasty.

Concerning the study of the diseased area, macroscopically it is very difficult to find which area must be selected for histologic evaluation. Furthermore, in our study we evaluated the size of the ventricular infarction to demonstrate the reduction of the size of the scar.

Dr Hikaru Matsuda (Osaka, Japan). We have been conducting a similar study of transfecting angiogenic growth factor to the ischemic myocardium. Instead of VEGF, we used hepatocyte growth factor, and the difference compared with your study is striking. Namely, the combined therapy with hepatocyte growth factor and cell transplantation showed apparently better results in function than those with the single therapy (cell transplantation or growth factor). My question is this: what did you expect the survivals of the cells to be in the cell transplantation alone group compared with the combined group? We have assumed that the growth factor may have a role in giving the blood supply to implanted cells, thus providing better survival and subsequent functional improvements.

Dr Chachques. One of the points that must be studied in the future is the quantification of the number of cells, not only before implantation but mainly after implantation (rate of cell survival). This was not performed in this study. The histologic samples that we analyzed seemed to show that the number of viable cells did not improve with the simultaneous combination of angiogenic growth factors. This was observed in our qualitative analysis.

I also want to comment that in the past, we associated electrostimulation with cell therapy to induce contractility of infarcted areas, because skeletal myoblasts do not contract spontaneously after myocardial implantation. In the future, the combination of cell therapy, angiogenesis, and electrostimulation could be a better approach for myocardial ischemic disease. 